\title{
Sudan Subgrade Soils Characteristics
}

\author{
Dr.Mohammed Mahmoud Shallal, Prof. Dr.Salih Elhadi Mohammed Ahmed \\ Sudan University of Science \& Technology
}

\begin{abstract}
In this paper, Sudan climate and geographic features have been covered. Then a soil survey for Sudan soil types has been carried out. The locations of soil samples have been chosen in accordance with the Climatic Zones Classifications for Sudan. Two basic tests conducted comprising: Grain Size Distribution and Atterberg Limits on each sample. And accordingly the soil classification has been determined for each sample. The soil type of each climate zone has been determined.
\end{abstract}

Key words: - subgrade soil, Climate zones, soil testing, soil properties

\section{INTRODUCTION}

Subgrade is defined as the soil prepared and compacted to support a structure or a pavement system. It is the foundation for the pavement structure. Subgrade soil or material sometimes is called (basement) or (foundation soil). The change of subgrade properties requires different thicknesses of pavement layers in order to support the same traffic load and produce the same performance. ${ }^{(1)}$

\section{SUDAN GEOGRAPHICAL FEATURES}

Sudan encompasses an area of about $1,861,484 \mathrm{sq} \mathrm{km}$. It is composed of vast plains interrupted by a few widely separated ranges of hills and mountains. Northern Sudan, lying between the Egyptian border and Khartoum, has two major district parts, the desert and the Nile Valley. To the east of the Nile lies the Nubian Desert and to the west lies the Libyan Desert. They are similar stony, with sandy dunes drifting over the land escape. There is virtually no rainfall in these deserts, and in the Nubian Desert there are no oases. In the west there are few small watering holes, where the water table reaches the surface to form wells that provide water to nomads, although insufficient for a settled population. Flowing through the desert is the Nile Valley provides lands not more than two kilometers wide as good land for agricultural activities. Western Sudan is a generic term describing the regions known as Darfur and Kordofan that comprise 850000 square kilometers. Western Darfur stands in stark contrast to northern and southern Darfur, which are semi desert with little water either from intermittent streams known as wadis or from wells that normally go dry during the winter months. One of the features of western Sudan is the Nuba Mountains range of southeast Kordofan. Many hills are isolated and extend only for few square kilometers, but there are several large hill masses with internal valleys that cut through the mountains high above the plain. Sudan third district region is the central clay plains that stretch eastward from the Nuba Mountains to the Ethiopian frontier, broken only by the Ingessana Hills, and from Khartoum in the north to the far South of Sudan. Northeast of the central clay plains lies eastern Sudan, which is divided between desert and semi desert and includes Albutana, Qash Delta, Red Sea Hills and the coastal plain. Albutana is an undulating land between Khartoum and Kassala. The Qash Delta originally is a depression filled with sand and silt brought down by the floods of the Qash River, creating a delta above the surrounding plains. In this area the soil is rich moist soil. Northward beyond the Qash Delta lie the Red Sea Hills and they stretch northward into Egypt. Below the hills, sprawls the coastal plain of the Red Sea, varying in width from about fifty six kilometers in the south near Twaker town to about twenty four kilometers near the Egyptian frontier. ${ }^{(2)}$ 


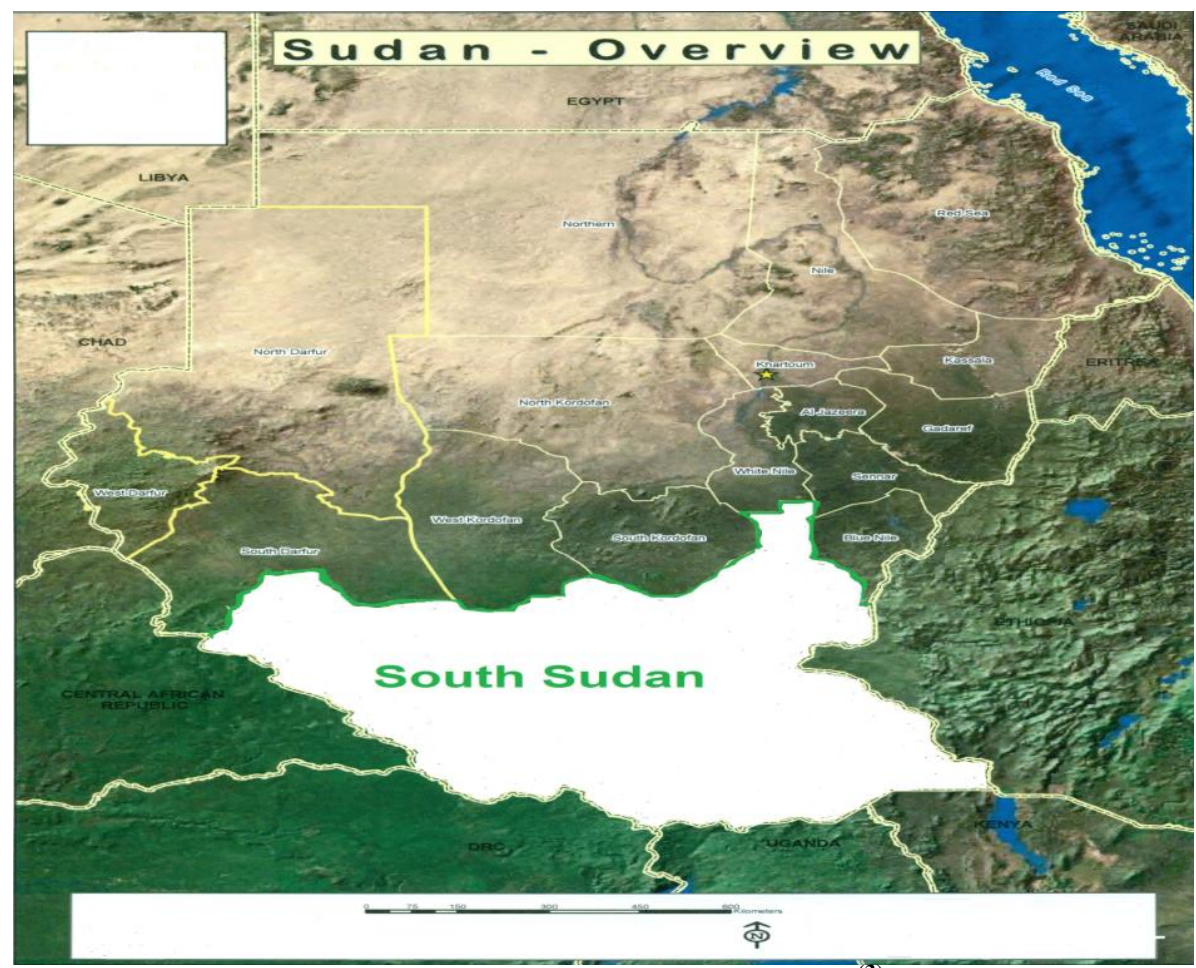

Figure (1): Sudan Satellite Imagery

The Remote Sensing Authority (RSA) of Sudan in collaboration with FAO SIFSA project (Sudan Integrated Food Security Information for Action), and the Ministry of Agriculture, produced a multipurpose Sudan Land Cover database 2003 and 2011. One of its results was Sudan Climate Zones, which were as follows: ${ }^{(4)}$

- Hyper Arid

- Arid

- Semi Arid

- Dry Sub Humid

- Moist Sub Humid

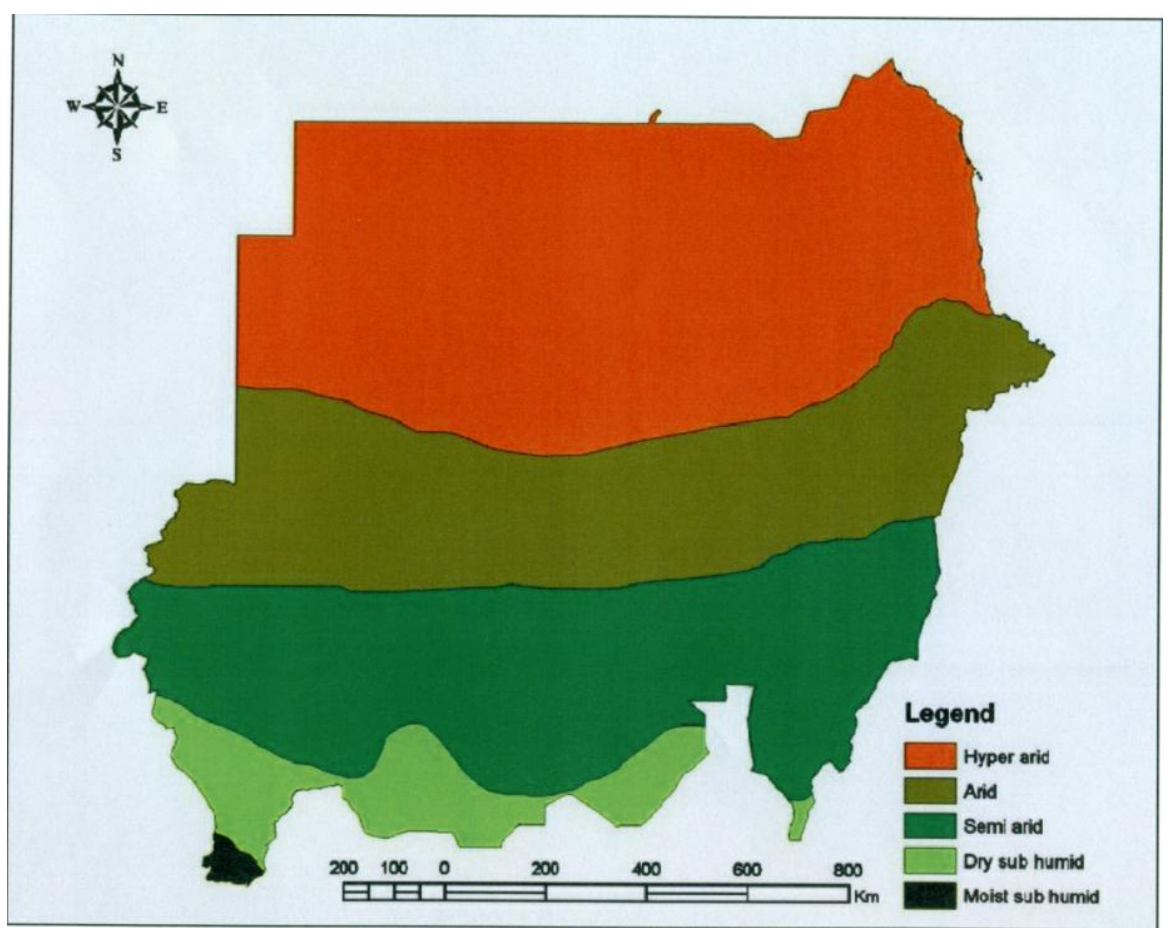

Figure (2): Climate Zones by means of Remote Sensing (4) 


\section{SOIL SURVEY}

3.1 Locations: A soil survey has been carried out, and 10 samples have been brought from 10 different locations all over Sudan. The samples locations have been determined in accordance with the climatic zones. These locations comprised:

\begin{tabular}{|c|c|c|}
\hline \multicolumn{3}{|c|}{ Table (1): Tests Locations: } \\
\hline No. & Sample Location & Climate Zone \\
\hline 1 & North East of Karima & Hyper Arid \\
\hline 2 & South East of Abuhamad & Hyper Arid \\
\hline 3 & Osaif & Hyper Arid \\
\hline 4 & South west of Toker & Arid \\
\hline 5 & West of Almatama & Semi Arid \\
\hline 6 & Kassala & Semi Arid \\
\hline 7 & 24 Elgurashi & Dry Sub Humid \\
\hline 8 & Kadugli & Dry Sub Humid \\
\hline 9 & Almujlad & Dry Sub Humid \\
\hline 10 & Algadarif & \\
\hline
\end{tabular}

3.2 Sampling: The types of equipments used in sampling comprised hole diggers and shovels. The depth of each test pit was not less than 1.5 meter. Samples have been kept in sealed containers to prevent moisture loss. Labels have been put inside the containers. Also full description for each sample has been clearly written from outside. ${ }^{(5)}$ The following picture shows an example for the soil testing pits:

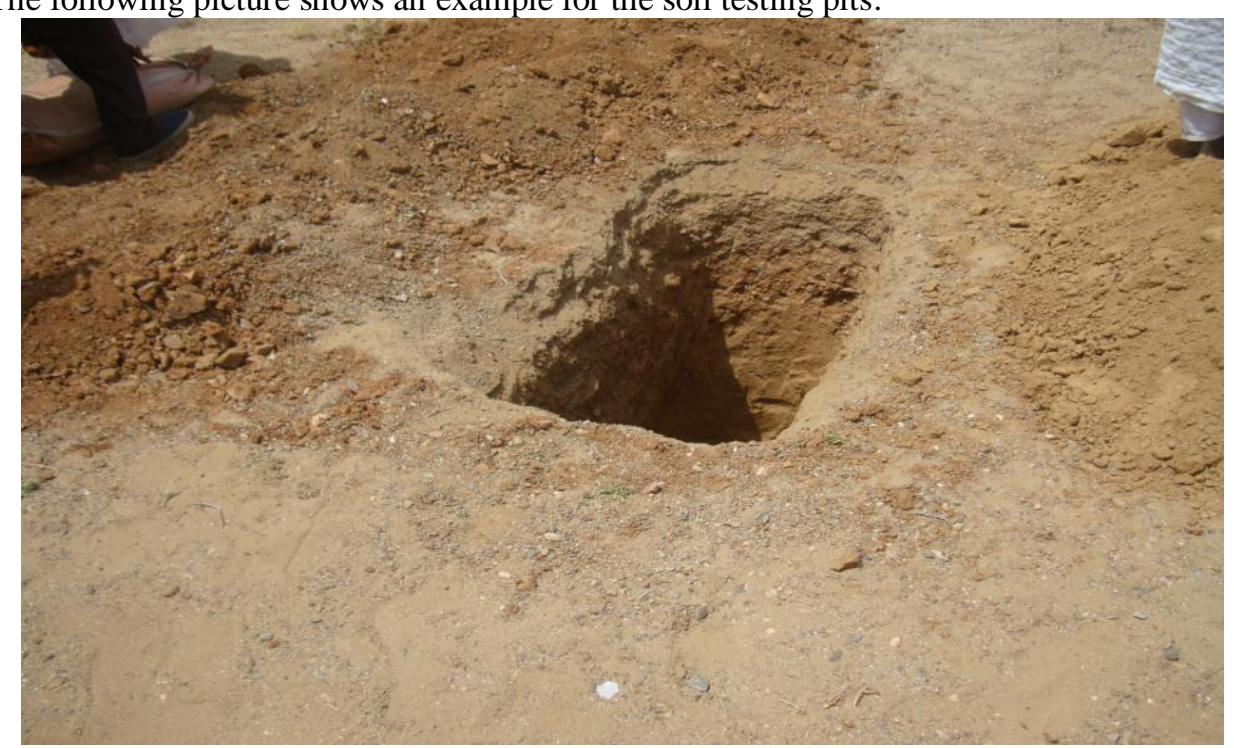

Figure (1): soil Testing Pit

\subsection{Testing:}

3.2.1 Testing Criteria: Tests conducted on the samples comprised Gradation, Atterberg Limits (Liquid Limit, Plastic Limit, and Plasticity Index), Compaction Test and CBR Test. Table (3-8) hereunder describes tests designations and the purpose for these tests.

Table (2): Subgrade soil tests criteria: ${ }^{(5),(6)}$

\begin{tabular}{|c|c|c|c|c|}
\hline $\begin{array}{c}\text { Common } \\
\text { Name of Test }\end{array}$ & Use & \multicolumn{2}{|c|}{ Test Method } & \multicolumn{2}{|c|}{ Purpose of Test } \\
\cline { 3 - 5 } Liquid Limit & Classification & AASHTO & ASTM & T 89 \\
Plastic Limit & Classification & T 8318 & $\begin{array}{c}\text { To find the water content at the boundary } \\
\text { between the liquid and plastic states of a soil. }\end{array}$ \\
\hline $\begin{array}{c}\text { Plasticity } \\
\text { Index }\end{array}$ & Classification & T 90 & D 4318 & $\begin{array}{c}\text { To find the water content at the boundary } \\
\text { between the plastic and semisolid states of a soil. }\end{array}$ \\
\hline $\begin{array}{c}\text { Mechanical } \\
\text { Analysis }\end{array}$ & Classification & T 88 & D 422 & $\begin{array}{c}\text { To find the range of water contents over which } \\
\text { the soil is in a plastic state. }\end{array}$ \\
\hline
\end{tabular}


3.2.2Testing Method: The test methods followed in conducting these tests have been concluded as follows:

> Particle Size Analysis: This test method covers the quantitative determination of the distribution of particle sizes in soils. The distribution of particle sizes larger than $75 \mu \mathrm{m}$ (retained on the No.200 sieve) is determined by sieving, while the distribution of particle sizes smaller than $75 \mu \mathrm{m}$ is determined by a sedimentation process, using a hydrometer to secure the necessary data. ${ }^{(5)}$

Liquid Limit and Plastic Limit Tests: The specimen is processed to remove any material retained on sieve No.40. The liquid limit is determined by performing trials in which a portion of the specimen is spread in a brass cup, divided in two by a grooving tool, and then allowed to flow together from the shocks caused by repeatedly dropping the cup in a standard mechanical device. The multipoint Liquid Limit, Method A, requires three or more trials over a range of water contents to be performed and the data from the trials plotted or calculated to make a relationship from which the liquid limit is determined. ${ }^{(5)}$

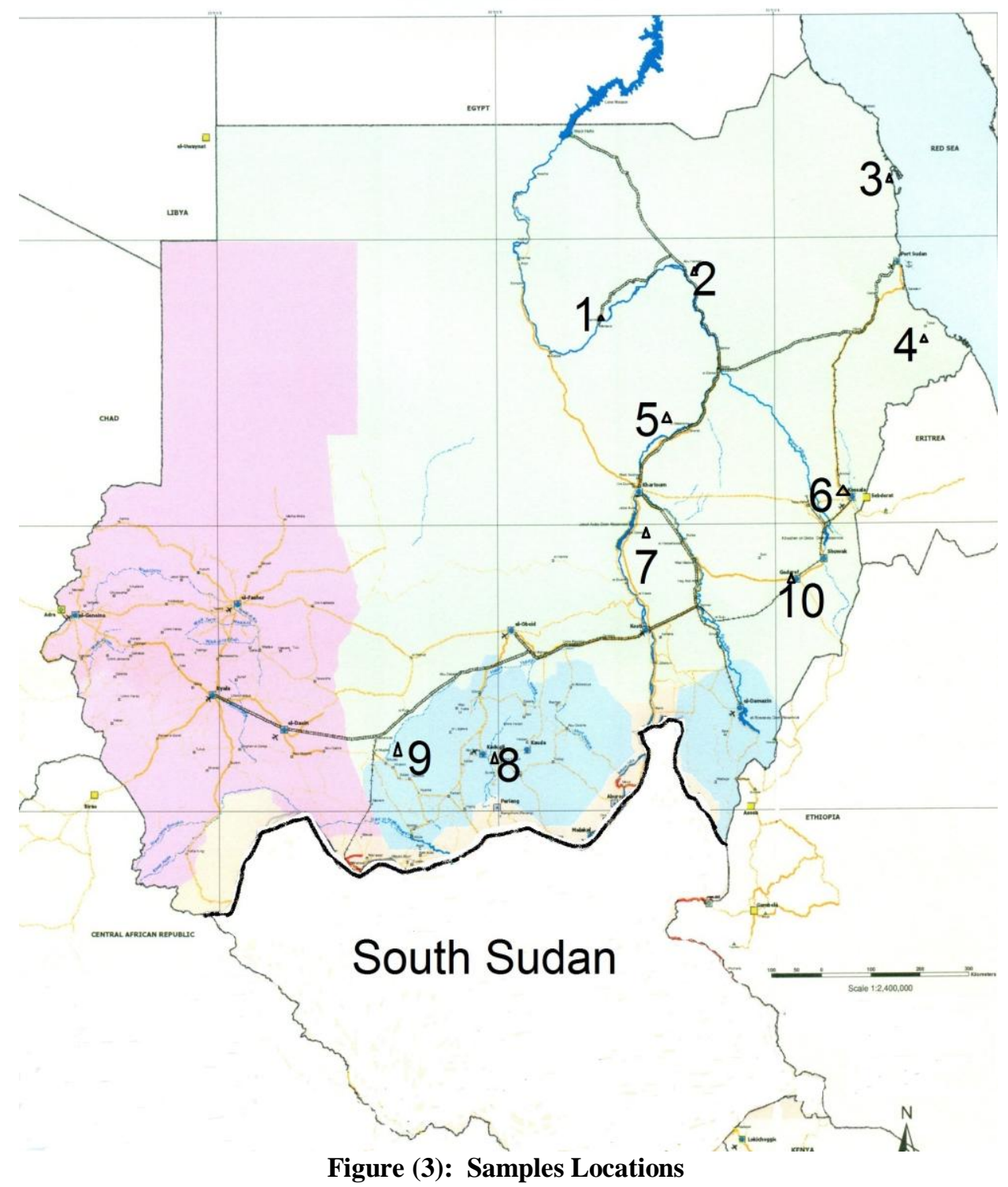

3. Soil Investigation Results and Analysis: The Grain Size Distribution, and Atterberg Limits. The results were as follows:

1. North East of Karima: Poorly graded sand, classified as A - 3 


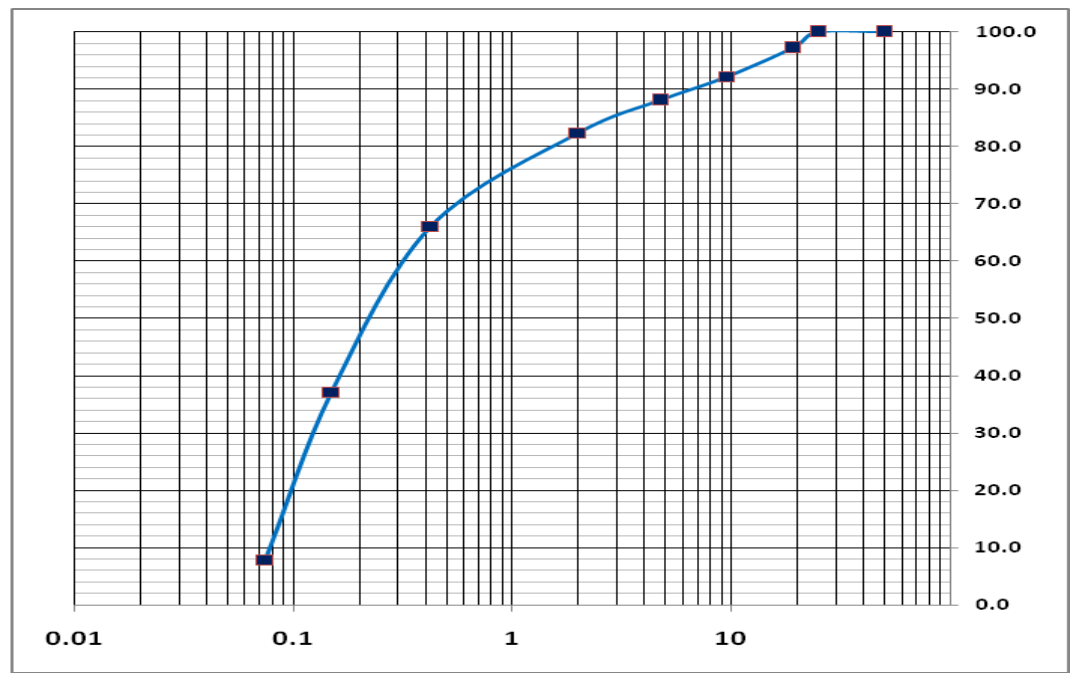

2. South East of Abuhamad: Poorly graded silty sand, classified as A - 3

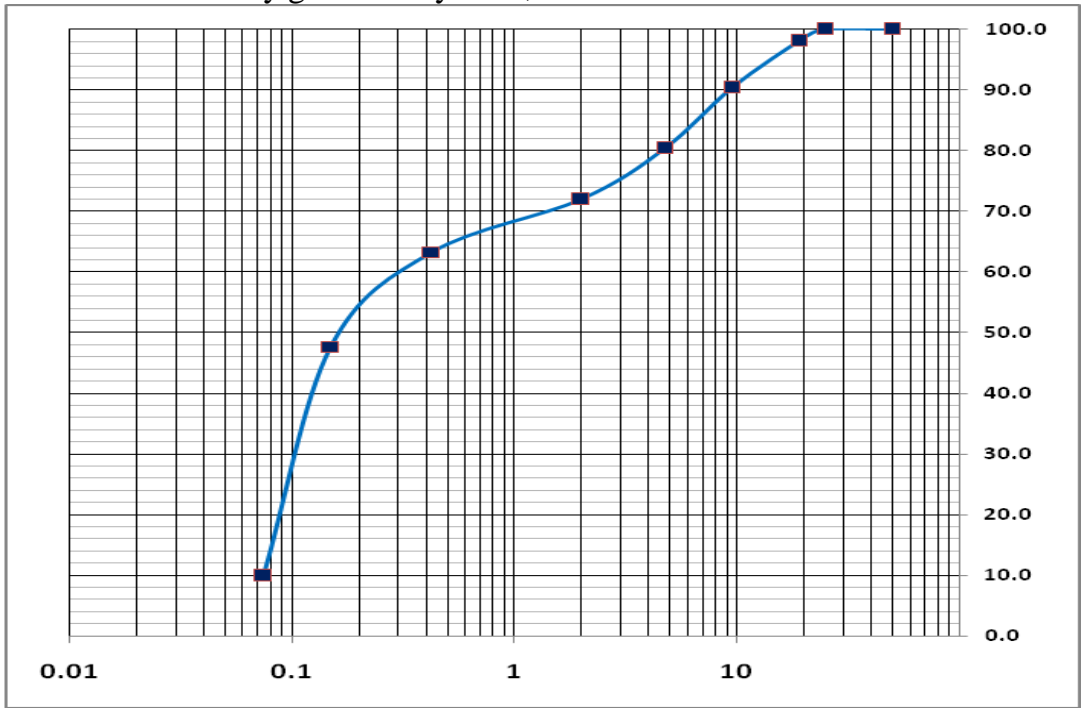

3. Osaif: Silty sandy Gravel, classified as A-1-b

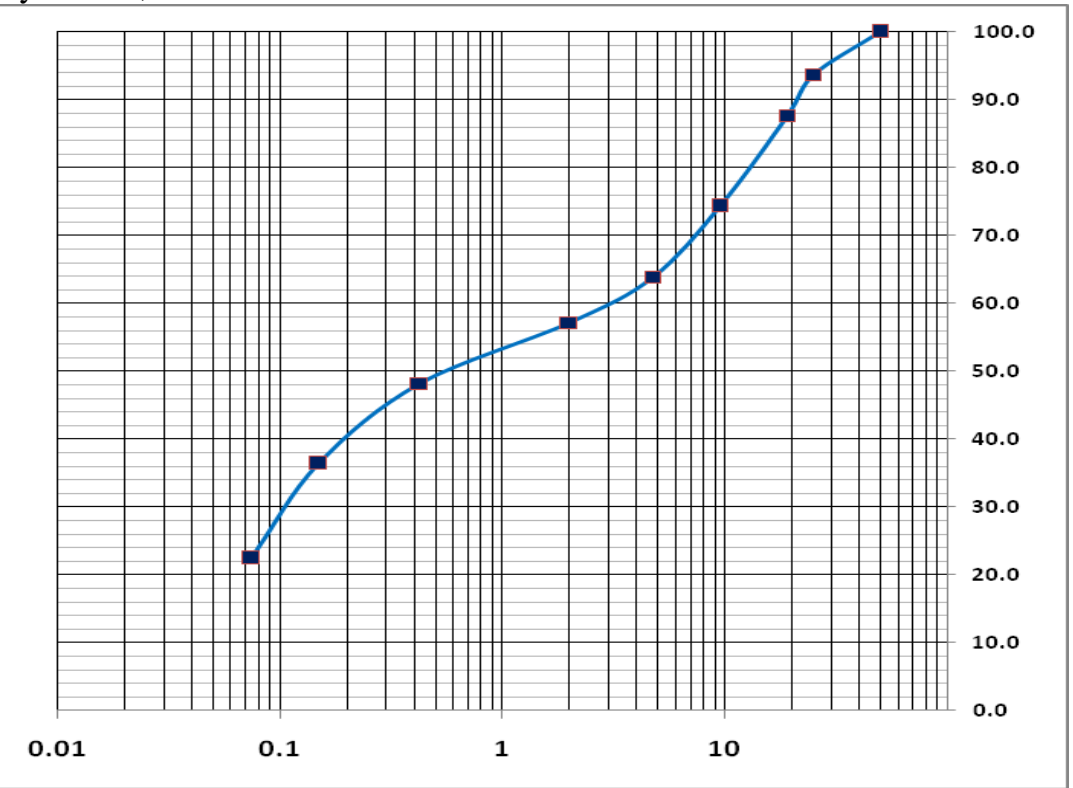


4. South west of Toker: Silty Gravelly sand, classified as A-1-b

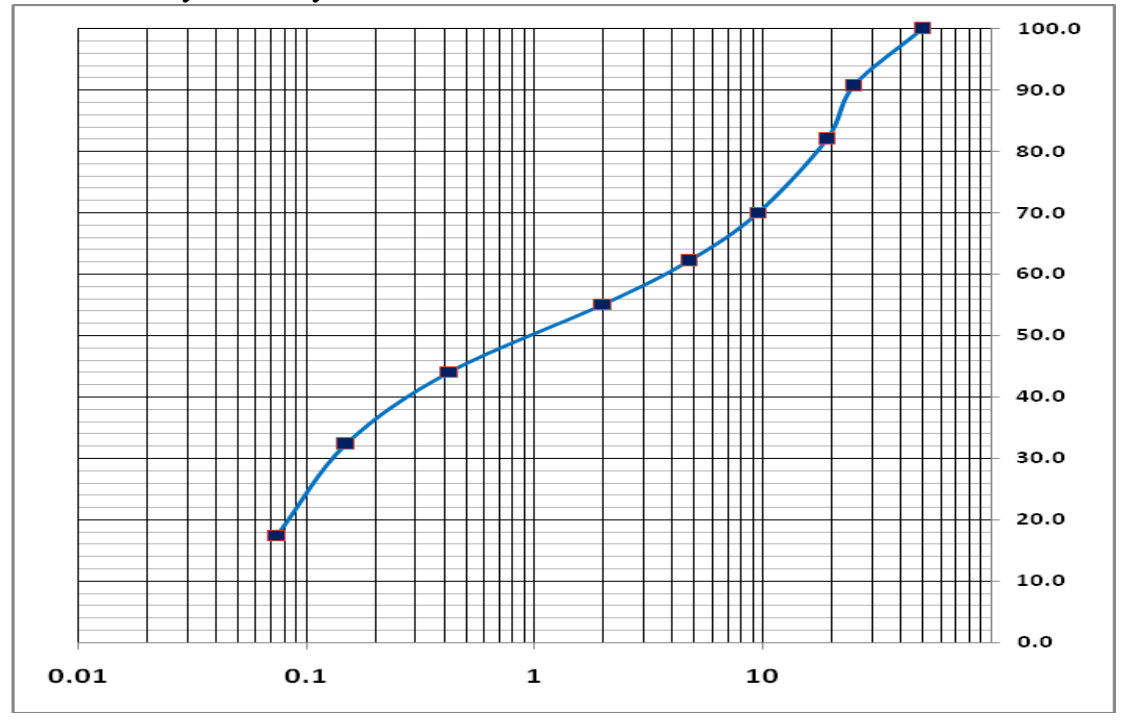

5. West of Almatama: Gravelly Silty sand, classified as A-2-4

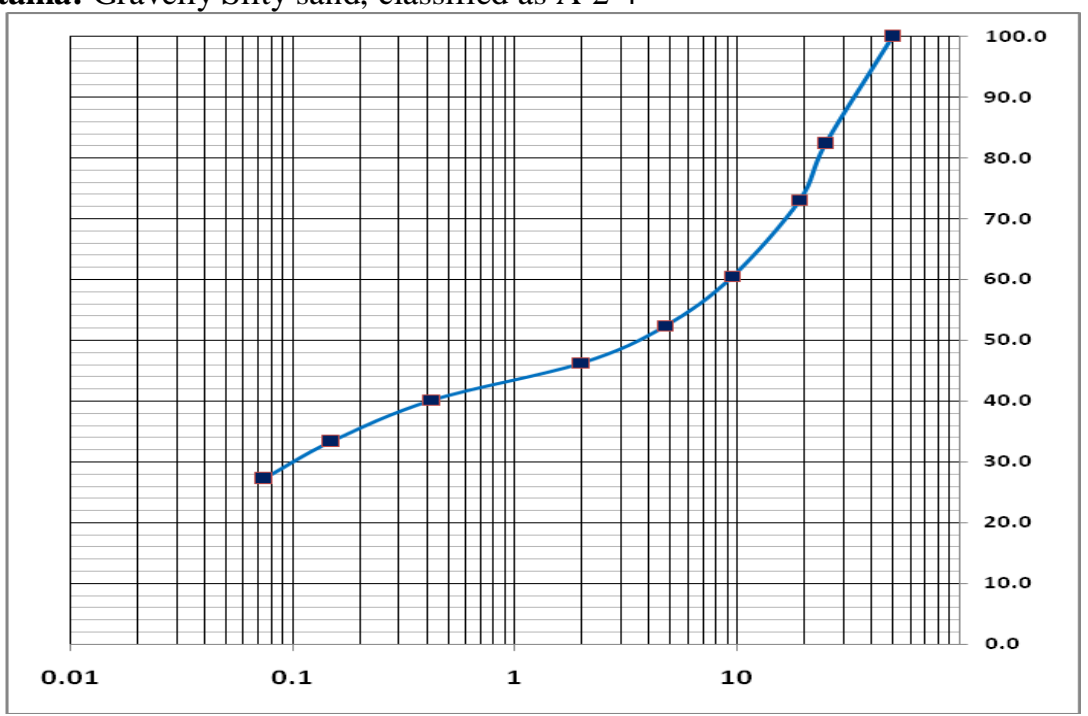

6. Kassala: Clayey Silty sand, classified as A - 4

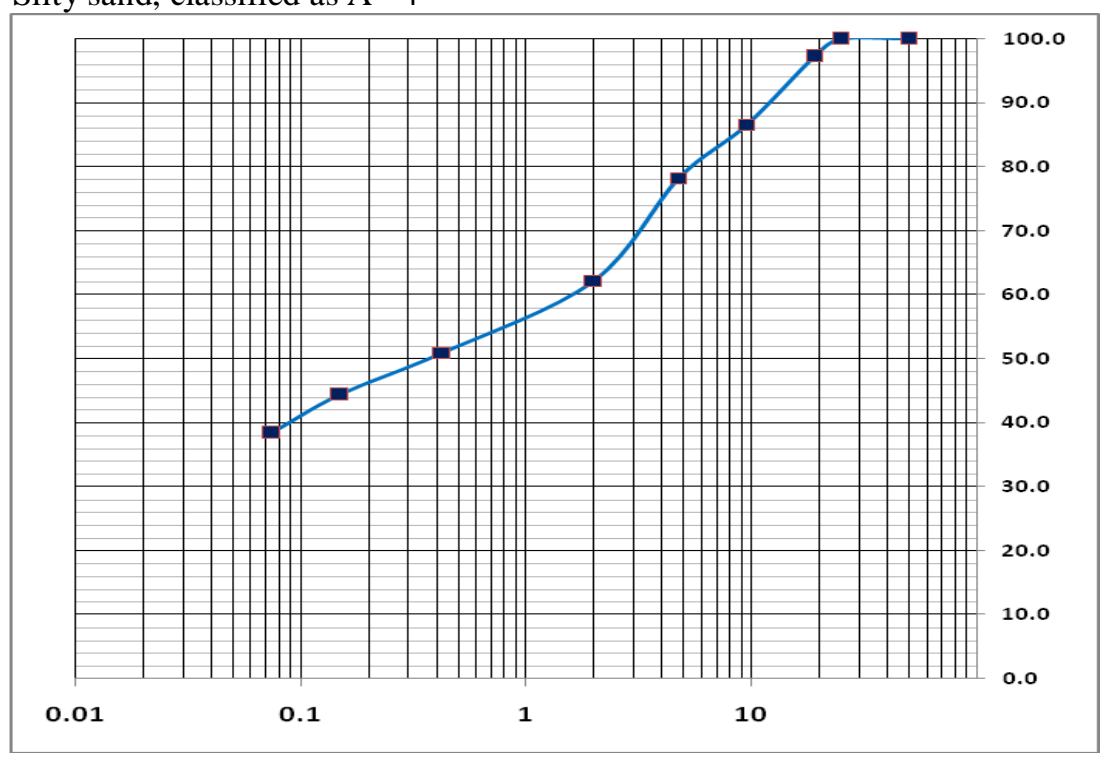


7. (24 Elgurashi): Silty Clay, classified as A-7-6

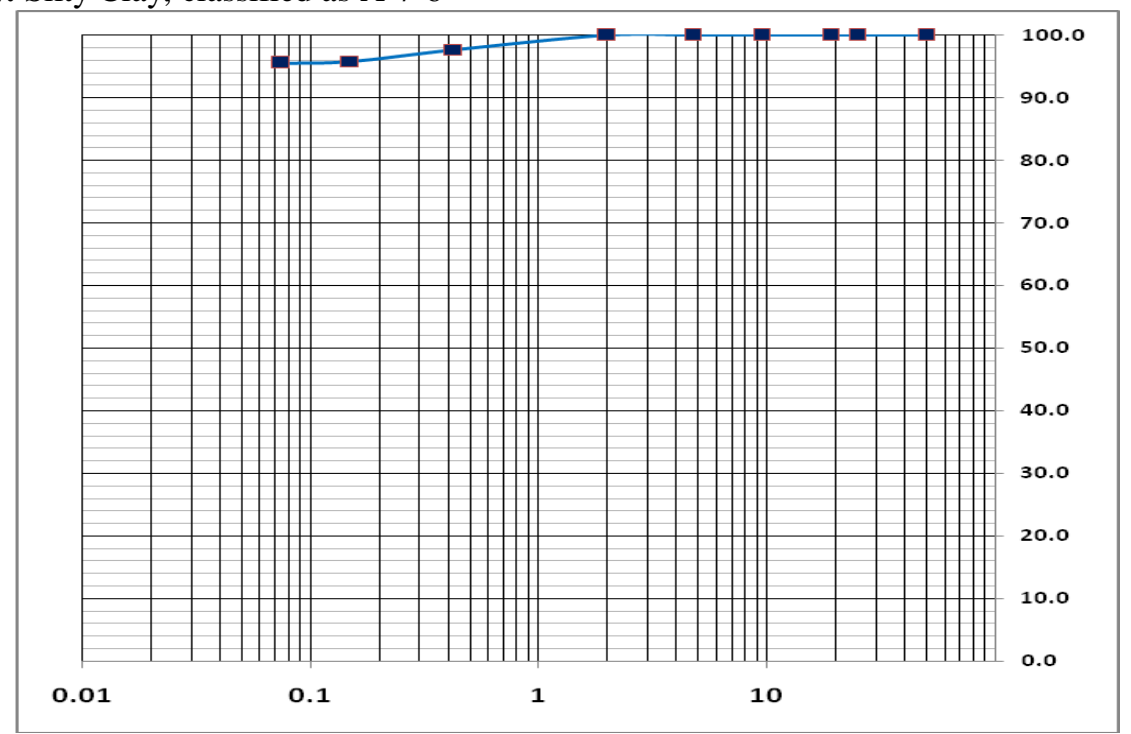

8. Kadugli: Sandy Silty Clay, classified as A-7-5

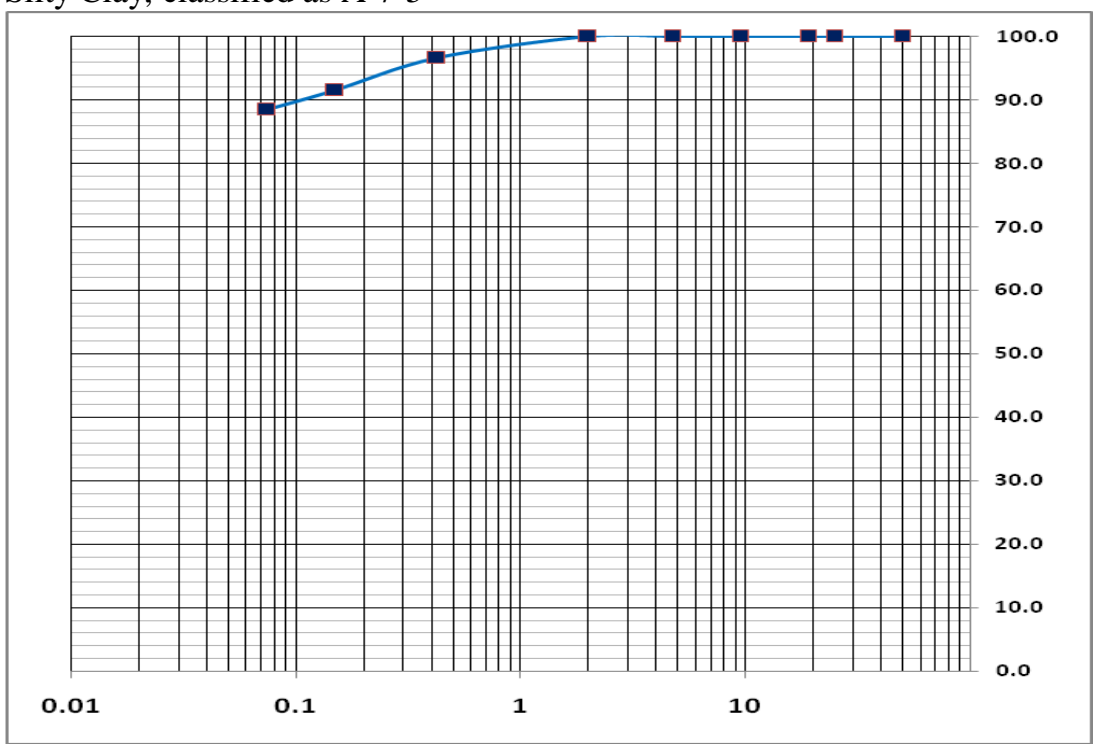

9. Almujlad: Silty Clay, classified as A-7-5

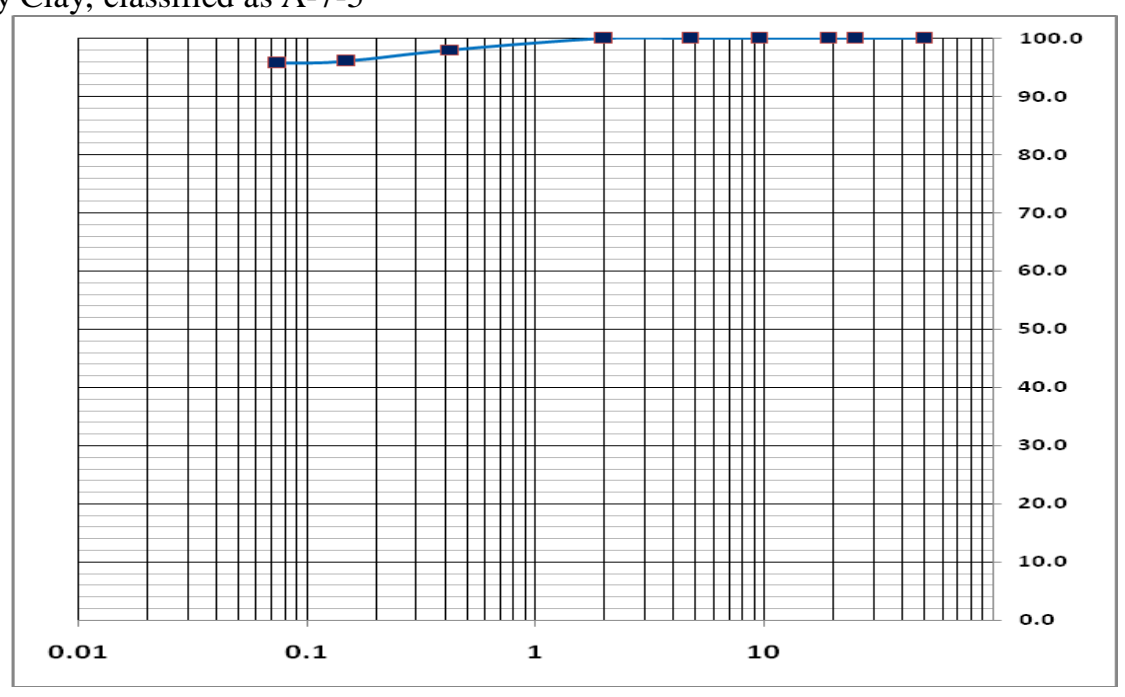


10. Algadarif: Silty Clay (Expansive Soil), classified as A-7-6

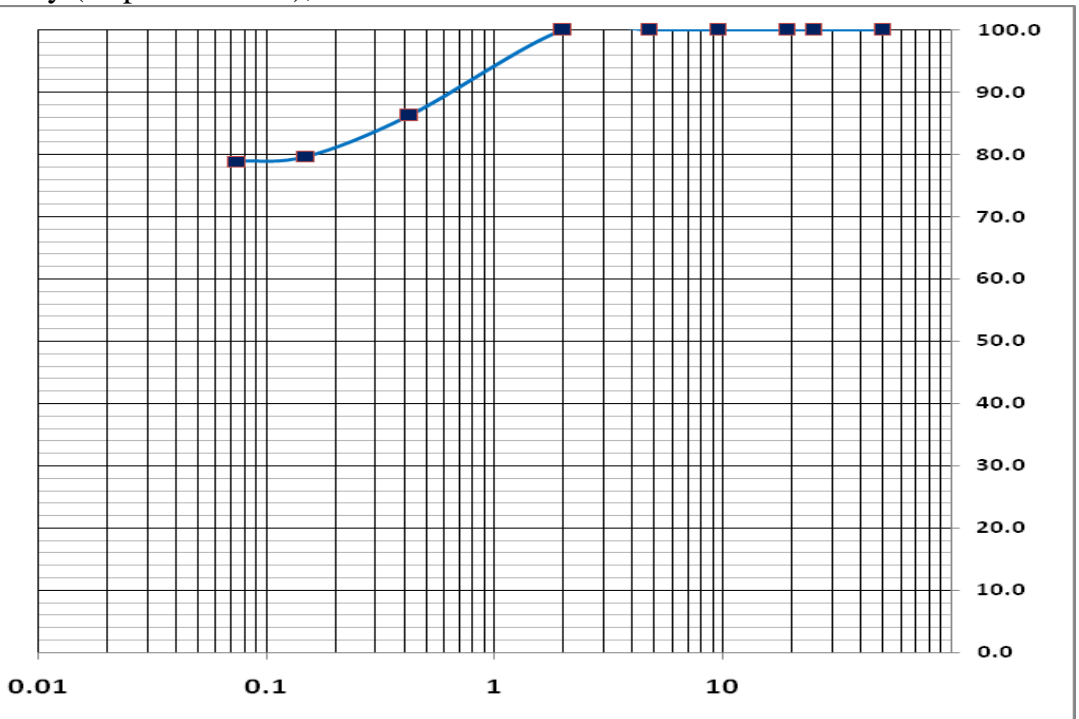

4. Summary of Results: The results summary is as follows:

\begin{tabular}{|c|c|c|c|c|}
\hline No. & Sample Location & Climate Zone & Classification & Description \\
\hline 1 & North East of Karima & Hyper Arid & A - 3 & Poorly graded sand \\
\hline 2 & $\begin{array}{c}\text { South East of } \\
\text { Abuhamad }\end{array}$ & Hyper Arid & A - 3 & Poorly graded silty sand \\
\hline 3 & Osaif & Hyper Arid & A-1-b & Silty sandy Gravel \\
\hline 4 & South west of Toker & Arid & A-1-b & Silty Gravelly sand \\
\hline 5 & West of Almatama & Arid & A-2-4 & Gravelly Silty sand \\
\hline 6 & Kassala & Semi Arid & A-7-6 & Silty Clay \\
\hline 7 & 24 Elgurashi & Semi Arid & A-7-6 & Silty Clay \\
\hline 8 & Kadugli & Dry Sub Humid & A-7-5 & Sandy Silty Clay \\
\hline 9 & Almujlad & Dry Sub Humid & A-7-5 & Silty Clay \\
\hline 10 & Algadarif & Dry Sub Humid & A-7-6 & Silty Clay (Expansive Soil) \\
\hline
\end{tabular}

IV. CONCLUSION

The subgrade soil survey and investigations carried out have shown the following:

- The Hyper Arid Climate Zone: the soil types encountered are poorly graded sand, become Silty sandy Gravel in the area of Red Sea Mountains.

- The Arid Climate Zone: the soil types encountered are Silty Gravelly sand and Gravelly Silty sand.

- The Semi Arid Climate Zone: the soil types encountered are Silty Clays.

- The Dry Sub Humid Climate Zone: the soil types encountered are Sandy Silty Clay, Silty Clay and Silty Clay (Expansive Soil).

- Generally Sudan has large expanses of homogeneous soils, expansive clay in the east-central area and Qoz sands in the center.

\section{RECOMMENDATIONS}

1. The data obtained is very helpful in the designing of roads at the various locations in Sudan, and correct assumptions can be obtained at the reconnaissance surveys with no need for sampling and testing.

2. More effort is needed in studying the different soil types in Sudan to arrive at very precise soil map.

\section{REFERENCES}

[1] Asphalt Institute, 2008, Asphalt Pavements for Highways \& Streets, Manual Series No.1 (MS-1), 9th edition, Lexington, KY, USA.

[2] Dr.Mahgoub G.Zaroug, Information Product, FAO, 2006, Country Pasture \& Forage Resource Profiles of Sudan.

[3] United Nations, Department of Field Support, Cartographic section.

[4] Amna A.Hamid, Eltayeb O.Adam \& Yahya H.Eltayeb, Remote Sensing Authority-Sudan, paper on "Land Cover as a Base for Food Security in Sudan", 
[5] American Society of Testing \& Materials (ASTM), Annual Book of ASTM Standards 2009.

[6] American Association of State Highways and Transportation Officials (AASHTO), 2012, Standard Specifications for Transportation Materials and Methods of Sampling and Testing, USA.

[7] George B. Sowers, 1979, Introductory Soil Mechanics and Foundations: Geotechnical Engineering, 4th Edition, Macmillan Publishing Co., Inc., New York, Collier Macmillan Publishers, London.

[8] British Standards Institution, 1975, Methods of Tests for Soils for Civil Engineering Purposes, London.

[9] Kenya Ministry of Transport and Communication of, 1995, Road Design Manual, Kenya.

[10] Adam H.S, 1998,"Agriculture Research Corporation, Land Conservation in the Arid Zone", (in Arabic), Sudan.

[11] Ministry of Works, Housing, and Communications, 2005, Road Design Manual, volume 3: Pavement Design, Part1: Flexible Pavements, The Republic of Uganda.

[12] Mohammed Mahmoud Shallal, 2010, A Guide of Standard Structural Design for Khartoum State Roads, published by Sudan Engineering Journal, volume 56, Sudan.

[13] CAO' Flaherty, 1981, Highway Engineering, volume two, USA. 